\title{
PERLINDUNGAN DESAIN INDUSTRI BAGI UMKM YANG BERKEADILAN SOSIAL
}

\author{
Sukarmi \\ Dosen Fakultas Hukum UNISSULA \\ sukarmi_sh@yahoo.com
}

\begin{abstract}
The setting of Industrial Design in Indonesia is the result of transplantation of TRIP's Agreement and Paris Convention for the Protection of Industrial Property (Paris Convention) the capitalist paradigm. These regulations are difficult to implement optimaly, because of the different of the values and cultures background. However, due to the juridical and psychological consequences, Indonesia has agreed GATT (General Agreement on Tariffs and Trade) and also agreed framework of the GATT/ WTO (World Trade Organization), Indonesia finally ratified through Law No. 7 Year 1994. The great hope of Industrial Design Act can be implemented, but the fact the contrary Law No. 31 of 2000 is still not optimal effect mainly by SMEs. It is evident the longer the number of applicants was even more reduced due to the degradation of Creativity and do not meet the values of social justice. It is prove that the number of applicants was even more reduced due to the degradation of Creativity and do not meet the values of social justice. Alternative step in bridging is done internalization of the values of Pancasila into the Industrial Design Act as "a spirit or soul" that is expected to provide justice for the designer (SMEs), further, it can development of creativity.
\end{abstract}

Keywords : Protection, Industrial Design, social justice

\begin{abstract}
Abstrak
Pengaturan Desain Industri di Indonesia merupakan hasil transplantasi dari TRIP's Agreement dan Paris Convention for the Protection of Industrial Property (Konvensi Paris) yang berparadigma kapitalis. Peraturan ini sulit untuk diimplementasikan secara optimal, karena nilai dan kultur yang melatar belakangi berbeda. Namun karena konsekwensi yuridis dan psikologis, Indonesia telah menyepakati GATT (General Agreement on Tariff and Trade) dan sepakat pula kerangka GATT/ WTO (World Trade Organization), akhirnya Indonesia meratifikasi melalui UU No. 7 Tahun 1994.

Harapan besar Undang-undang Desain Industri dapat dimplementasikan, tetapi fakta sebaliknya Undang-Undang Nomor 31 tahun 2000 masih belum optimal berlaku terutama oleh UMKM. Hal ini terbukti jumlah pendaftar semakin lama justru semakin berkurang karena terjadi Degradasi Kreatifitas dan belum memenuhi nilai-nilai keadilan sosial. Langkah alternatif dalam menjembatani adalah dilakukan internalisasi nilai-nilai pancasila ke dalam UndangUndang Desain Industri sebagai "roh atau jiwa" yang diharapkan mampu memberikan keadilan bagi masyarakat Pendesain (UMKM), sehingga dapat memacu pengembangan kreativitas Pendesain selanjutnya.
\end{abstract}

Kata Kunci : Perlindungan, Desain Industri, keadilan sosial.

\section{A. Latar Belakang}

Lahirnya Undang-undang Desain Industri di Indonesia dilatarbelakangi oleh adanya 2 (dua) alasan. Alasan pertama, terkait masalah kewajiban Indonesia sebagai anggota World Trade
Organization (WTO) yang harus menyediakan peraturan yang lebih baik tentang perlindungan Desain Industri. Kedua, berhubungan dengan tekad pemerintah untuk memberikan perlindungan yang efektif terhadap berbagai bentuk pelanggaran 
terhadap desain industri seperti penjiplakan, pembajakan atau peniruan. Upaya perlindungan yang lebih komprehensif tersebut diharapkan dapat menjadi faktor pendorong untuk meningkatkan daya kreativitas para pendesain dan sebagai wahana untuk melahirkan para pendesain yang produktif. $^{1}$

Kebijakan ikut sertanya Indonesia sebagai anggota World Trade Organization (WTO) sebagai salah satu bukti keseriusan Pemerintah dalam mendukung sistem perekonomian bebas/terbuka yang secara tidak langsung memacu perusahaanperusahaan untuk lebih meningkatkan daya saing. Ratifikasi terhadap Agreement Establishing the World Trade Organization (Persetujuan Pembentukan Organisasi Perdagangan Dunia) mencakup Agreement on Trade Related Aspects of Intellectual Property Rights (Persetujuan TRIP's) melalui pengesahan Undang-undang Nomor 7 Tahun 1994. Kondisi tersebut telah mendukung ratifikasi Paris Convention for the Protection of Industrial Property (Konvensi Paris) dengan keputusan Presiden Nomor 15 Tahun 1997 dan keikut sertaan Indonesia dalam the Haque Agreement (London Act) concerning the International Deposit of Industrial Designs. Prinsip pengaturannya adalah pengakuan kepemilikan atas karya intelektual yang memberikan kesan estetis dan dapat diproduksi secara berulangulang serta dapat menghasilkan suatu barang dalam bentuk 2 (dua) atau 3 (tiga) dimensi. ${ }^{2}$

Indonesia menyikapi dan mengambil suatu langkah cerdas. dengan keberadaan nilai-nilai dan kulturnya masing-masing dalam upaya untuk bisa menerapkan Undang-undang Desain Industri yang berpadigma kapitalis bertolak belakang dengan paradigma yang telah berakar di Negara Indonesia. Namun karena konsekwensi yuridis dan psikologis Indonesia telah menyepakati GATT (General Agreement on Tariff and Trade) dan sepakat pula kerangka GATT/ WTO (World Trade Organization), dan diratifikasi melalui UU No. 7 Tahun 1994, berharap

1 Tomi Suryo Utomo, 2009, Hak Kekayaan Intelektual (HKI) di Era Global (Sebuah Kajian kontemporer), hlm. 225.

2 Ditjen HKI, 2007:13; JPO dan JII, 2007:110 dalam Ibid. Tomi Suryo Utomo,2009, Hak Kekayaan Intelektual (HKI) di Era Global (Sebuah Kajian kontemporer), hlm. 229. besar Undang-undang Desain Industri tersebut dapat diimplemetasikan dan bermanfaat bagi masyarakat Indonesia pada umumnya termasuk alih tehnologi, walaupun faktanya sampai kini berbeda. Sehingga akhirnyapun kembali menjadi suatu polemik dan persoalan yang cenderung menempatkan Negara pada posisi yang sulit dan tertindas. ${ }^{3}$

Awalnya Desain Industri diatur pada abad ke-18 di Inggris masih berbentuk 2 (dua) Dimensi, menjadi bentuk 3 (tiga) Dimensi diatur melalui Sculpture Copyright Act 1798 hanya meliputi model manusia dan binatang. Tanggal 20 Maret 1883 The Paris Convention for the Protection of Industrial Property (Paris Convention). Pasal 5 Paris Convention menyatakan bahwa Desain Industri harus dilindungi di semua negara anggota Paris Convention. ${ }^{4}$ Fakta yang terjadi berbeda, karena perlindungan hukum yang diharapkan belum memenuhi rasa keadilan sosial. Upaya perlindungan yang lebih komprehensif terus dilakukan untuk meningkatkan daya kreativitas para Pendesain dan sebagai wahana untuk melahirkan para Pendesain yang produktif. ${ }^{5}$

Metode yang dipakai socio-legal Research dengan pendekatan juridis empiris, dengan analisis deskriptif kualitatif. Data yang dipergunakan adalah data primer, data sekunder. Responden diambil dari UMKM pengrajin kayu ukir di Kabupaten Jepara, baik dari kreator sendiri sebagai sampel maupun pihak lain yang bekerja untuk pendesain. Pasal 1 ayat (1) Undang-undang Desain Industri menyebutkan:

"Desain Industri adalah suatu kreasi tentang bentuk, konfigurasi, atau komposisi garis atau warna, atau garis dan warna, atau gabungan daripadanya yang berbentuk tiga dimensi atau dua dimensi yang memberikan kesan estetis dan dapat diwujudkan dalam pola tiga

3 Ibid. Ok. Saidin, hlm. 6.

4 Perlindungan Desain Industri di Indonesia dan Ketentuan Internasional di Bidang Desain Industri. Mayana, R.F. 2011. Panitia Pelatihan Konsultan Hak Kekayaan Intelektual. Kerjasama antara Fakultas Hukum Universitas Padjajaran dan Direktorat Jenderal HKI Kementrian Hukum dan HAM RI, hIm. 4

5 Tomi Suryo Utomo, Hak Kekayaan Intelektual (HKI) di Era Global (Sebuah Kajian kontemporer), 2009, hlm. 225. 
dimensi atau dua dimensi serta dapat dipakai untuk menghasilkan suatu produk, barang, komoditas industri, atau kerajinan tangan."

Pasal sangat individualistis, yang menonjol dalam bentuk luaran terlihat tanpa menjiwai serta kurang mencerminkan rasa keadilan sosial maupun kebersamaan sebagaimana kultur atau budaya bangsa Indonesia. Disisi lain kekayaan budaya dan etnis bangsa Indonesia yang sangat beraneka ragam, baik dilakukan masyarakat berpendidikan rendah, menengah maupun tinggi, serta kreasipun beraneka ragam bentuk maupun model, dengan pengorbanan waktu, tenaga dan materi sampai kini masih banyak yang belum diakomodasi dengan baik, sehingga kreasi yang bersifat unik tersebut belum mendapatkan perlindungan hukum. Perlindungan hukum merupakan penghargaan yang diberikan kepada mereka Pendesain/Kreator yang mengajukan permohonan pendaftaran.

Teori perlindungan hukum dari Satjipto Raharjo, memberikan pengayoman terhadap masyarakat agar dapat menikmati semua hak yang sesuai hukum. ${ }^{6}$ Demikian juga Lili Rasjidi dan I.B Wyasa Putra, ingin mewujudkan perlindungan yang sifatnya tidak sekedar adaptif dan fleksibel tetapi juga prediktif dan antisipatif. ${ }^{7}$ Diperkuat pula oleh Sunaryati Hartono, bahwa hukum dibutuhkan dan diperuntukkan bagi mereka yang lemah dan belum kuat secara sosial, ekonomi dan politik untuk memperoleh keadilan sosial. ${ }^{8}$ Upaya untuk mendapatkan perlindungan hukum yang diinginkan oleh manusia adalah terwujudnya ketertiban dan keteraturan antara nilai dasar dari hukum yakni adanya kepastian hukum, kegunaan hukum serta keadilan hukum, meski pada umumnya yang sering terjadi dalam praktek ketiga nilai-nilai dasar tersebut sering bersitegang, tetapi harus diupayakan ketiga nilai dasar tersebut bersamaan. ${ }^{9}$ Berbeda Hadjon ada dua macam perlindungan hukum bagi rakyat 6 Ibid., hlm. 54.

7 Lili Rasjidi dan I.B Wysa Putra, Hukum Sebagai Suatu Sistem, (Bandung, Remaja Rusdakarya, 1993), hlm. 118.

8 Sunaryati Hartono, Politik Hukum Menuju Satu Sistem Hukum Nasional, (Bandung: Alumni, 1991), hlm. 55.

9 lbid. preventif dan represif. Prinsip perlindungan hukum bagi rakyat Indonesia adalah prinsip pengakuan dan perlindungan terhadap harkat dan martabat manusia yang bersumber pada Pancasila dan prinsip Negara Hukum yang berdasarkan Pancasila. ${ }^{10}$

Teori keadilan sosial, juga mewarnai sebagaimana terdapat pada alinea keempat Pembukaan UUD 1945. Bahwa keadilan sosial menjadi salah satu landasan dasar dari tujuan dan cita-cita negara (staatsidee) sekaligus sebagai dasar filosofis bernegara (filosofische grondslag) terdapat pada sila kelima dari Pancasila. Artinya, sudah sejak awal the founding parents mendirikan Indonesia atas pijakan untuk mewujudkan keadilan sosial baik untuk warga negaranya sendiri maupun masyarakat dunia. Relevansi Konstitusi teori keadilan dari John Rawls adalah bahwa prinsip-prinsip keadilan yang disampaikan sangat relevan bagi negara-negara dunia yang sedang berkembang, seperti Indonesia.

Reward Theory yang memiliki makna pengakuan terhadap karya intelektual yang telah dihasilkan oleh seseorang sehingga kepada kreator Pendesain harus diberikan penghargaan sebagai imbalan atas upaya-upaya kreatifnya dalam menemukan/atau menciptakan karya-karya intelektual tersebut. Teori ini sejalan dengan prinsip yang bahwa Inventor/Pendesain yang telah mengeluarkan waktu, biaya serta tenaga dalam menghasilkan karya intelektualnya harus memperoleh kembali apa yang telah dikeluarkan tersebut, yang dikenal dengan Recovery Theory. Selain Reward theory adalah Incentive Theory yang mengaitkan pengembangan kreatifitas dengan memberikan insentif bagi para penemu/ pencipta atau Pendesain tersebut. Dengan menganalisis ini dapat diraih keadilan sosial, yang sesuai dengan porsinya, sebagaimana yang terdapat nilai sila kelima Pancasila.

Ciri utama dalam Desain Industri adalah bahwa karya desain yang dapat diwujudkan dalam pola atau cetakan untuk menghasilkan barang-barang dalam proses produksi yang dapat dilakukan secara berulang-ulang. Industrialisasi Indonesia telah berdampak pada transformasi struktural

10 Phillipus M. Hadjon, Perlindungan Hukum Bagi Rakyat Indonesia", (Surabaya: PT. Bina IImu, 1987), hlm. 2 . 
di Indonesia, yang ditandai dengan semakin tingginya kontribusi sektor industri dan beberapa sektor lainnya, kontribusi sektor pertanian semakin kecil pada tahun 1968, sektor industri manufaktur Indonesia memberi sumbangan sebesar 8,5 persen terhadap keseluruhan perekonomian (PDB), sedangkan sektor pertanian menjadi sektor tertinggi untuk perekonomian, dengan kontribusi sebesar 51 persen. ${ }^{11}$

\section{B. Hasil dan Pembahasan}

Pasal 1 butir (1), Perlindungan Hukum diberikan pada bentuk luaran/tampilan luar (physical appearance) yang memberi kesan estetis dan bukan pada fungsi sebuah benda. Namun kesan estetis ini bersifat umum. Kreasi Desain Industri harus dipisahkan atau dibedakan dari benda itu, karena desain merupakan sebuah "konsep" yang diterapkan pada produk, barang, komoditas industri, atau kerajinan tangan dan tidak melekat menjadi satu dengan barangnya. "Pemegang Hak Desain Industri" yang memiliki hak eksklusif dapat melaksanakan dan melarang orang lain yang tanpa persetujuannya.

Subjek hak Desain Industri meliputi: 1) Pendesain atau yang menerima hak tersebut dari Pendesain, 2) Jika Pendesain terdiri atas beberapa orang secara bersama, Hak Desain Industri diberikan kepada mereka secara bersama, kecuali jika diperjanjikan lain. Pemegang Hak Desain Industri adalah pihak yang untuk dan/atau dalam Dinasnya Desain Industri itu dikerjakan, kecuali ada perjanjian lain dan Perlindungan Hukum Desain Industri menganut sistem Konstitutif dengan prinsip "First to File Principle". Konsekwensinya, jika suatu Desain Industri yang dimiliki tidak terdaftar, maka tidak akan mendapatkan perlindungan hukum. Sebagai contoh, di Kabupaten Jepara memiliki banyak Pendesain/Kreator, banyak belum mendapat prioritas karena kreativitas yang dimiliki masyarakat belum diapresiasi dengan maksimal oleh Pemerintah Daerah. Sehingga Undang-undang Desain Industri belum dapat dimanfaatkan secara optimal khususnya "Pendesain Meubel Ukir". Ada beberapa kendala

11 Mudrajad Kuncoro, Pemberdayaan UKM: Antara Mitos dan Realitas, (Ketua Jurusan dan Guru Besar di FE-UGM Yogyakarta), hlm. 1. yang timbul belum optimalnya hukum dapat diimplementasikan yang menurut Friedman karena substansi, struktur dan kulturnya belum sesuai dengan kondisinya. Substansi dari Undang-undang Desain Industri itu sendiri belum mampu memberikan perlindungan hukum yang mencerminkan nilai keadilan sosial, yang tidak mengakar dalam tradisi budaya masyarakat Indonesia yang tumbuh dalam tradisi hukum masyarakat Indonesia yang berakar pada budaya komunal (kebersamaan). Karena budaya UndangUndang Desain Industri yang berlaku kini dari sudut historisnya, adalah transplantasi dari produk kaum Kapitalis-Liberal. Masyarakat Pancasila mencari dan mengutamakan keseimbangan antara hidup sebagai pribadi dan hidup sebagai warga masyarakat, antara kehidupan materi dan kehidupan rokhani.

Sedangkan untuk mendapatkan Perlindungan Pendesain maupun produknya, harus melalui pengajuan Permohonan Pendaftaran ke Ditjen HKI Departemen Hukum dan HAM-RI. Di sisi lain: (1) Pendesain rata-rata adalah UMKM merasa belum tertarik untuk mendaftar, karena ketidaktahuan mereka terhadap arti penting dampak pendaftaran, juga belum ada perhatian khusus dari Pemerintah Daerah terhadap Perlindungan Pendesain/ Kreator Desain Industri, baik melalui upaya Pemberdayaan UMKM khususnya Desain Industri "mebel ukir"; (2) Belum faham kriteria Desain Industri yang termasuk dalam kategori bisa mendapatkan perlindungan hukum; (3) Belum mengerti dan memahami syarat-syarat yang harus dilengkapi untuk Permohonan Pendaftaran; (4) Belum tahu manfaat ekonomis dan yuridis dari Pendaftaran Desain Industri yang mereka ciptakan; (5) Kesulitan mengakses informasi dalam mengaplikasi Desain Industri ke Direktorat HKI Departemen Kehakiman dan HAM dan kurang sosialisasi dari Pemerintah Daerah terkait; (6) Sikap mistifikasi terhadap karya yang dihasilkan dan pengaruh konsep budaya (komunal) yang melekat pada konsep berpikir Pendesain/Kreator; (7) SDM kurang termotivasi secara optimal; (8) Tidak ada bimbingan dan pendampingan yang intensif serta tidak adanya pemberian/ subsidi biaya; (9) Tidak adanya kebijakan pola jemput bola dari Pemda setempat sebagai wujud kepedulian atau perhatian dan bantuan 
dari Pemerintah Daerah dalam menyiasati atau sebagai dana pancingan; (10) Undangundang tentang Perlindungan Pendesain pada Hukum Desain Industri belum memenuhi rasa keadilan sosial. Kekurang perhatian Pemerintah Daerah berdampak terjadinya beberapa kasus pembajakan/ penyerobotan seperti Kasus "Dugaan Eksploitasi Folklor Jepara oleh Christoper HarrisonInggris; Kasus penyerobotan pendaftaran yang dilakukan pengusaha mitra bisnis tanpa ijin, ke negara asal mitra kerjanya; yang berdampak terbalik desain tersebut jusru didaftarkan oleh mitra bisnis di negara asal mitra. Seperti dalam sebuah event pameran dengan cara memotret, orang lain bisa mendapatkan hak secara legal.

Pemegang Hak Desain Industri dapat beralih atau dialihkan dengan cara pewarisan, hibah, wasiat, perjanjian tertulis, melalui perjanjian lisensi atau sebab-sebab lain yang dibenarkan oleh peraturan perundang-undangan. Pengalihan Hak Desain Industri tersebut harus disertai dengan Dokumen tentang Pengalihan hak dan wajib dicatat dalam Daftar Umum Desain Industri, dengan membayar biaya, diumumkan dalam Berita Resmi Desain Industri.

1. Cara Memperoleh Hak Desain Industri Bagi masyarakat yang concern dalam bidang Hak Kekayaan Intelektual (HKI) mempertanyakan terkait dengan sistem Perlindungan Hukum dari HKI khususnya Desain Industri yang merupakan bagian dari HKI. Terbukti sampi kini Indonesia belum mampu memberikan perlindungan hukum dan pengelolaan atas kekayaan intelektual masyarakat Indonesia secara optimal, dan belum efektif. Salah satu faktor penyebab keengganan masyarakat pendesain untuk mendaftarkan desain kreatifnya, di samping kewenangan pengadministrasian $\mathrm{HKI}$ dan pengelolaan HKI di daerah belum dibentuk.

Pada prinsipnya setiap orang atau badan (kreator/pendesain) yang telah mendapat persetujuan dari Permohonan Pendaftaran Desain Industri ke Direktorat HKI maka mendapat Hak Desain Industri atau berhak untuk monopoli selama 10 (sepuluh) tahun. Pemegang Hak Desain Industri ini mempunyai hak untuk memberi izin atau melarang orang lain untuk membuat, menjual, mengimpor, mengekspor atau mengedarkan barang yang telah diberikan Hak Desain Industri. Abdul Bari Azed menegaskan, ${ }^{12}$ Desain Industri akan mendukung peningkatan pertumbuhan ekonomi. Bagaimanapun perlindungan terhadap Desain Industri akan meningkatkan desain kreatifitas dalam menciptakan bentuk produk yang beragam di sektor manufaktur serta kerajinan. Namun, pemerintah sangat minim melakukan sosialisasi mengenai Desain Industri, sehingga wajar bila kemudian ada ketidaktahuan masyarakat terhadap Desain Industri. Padahal fasilitas keringanan telah digulirkan untuk UMKM tetapi tingkat realisasinya masih sangat rendah. ${ }^{13} \mathrm{Ada}$ biaya khusus yang diberikan untuk UMKM, pelajar atau mahasiswa dalam mendaftarkan desainnya. Kelompok ini mendapat keringanan 50 persen dari Rp 600.000 setiap kali pendaftaran, berdasar Peraturan Pemerintah Nomor 50 Tahun 2001.

\section{Kurangnya Sikap Kesiapan Pendesain Terhadap Kreasinya}

Desain merupakan aset produk, bagian dari kreativitas manusia, dimana kreativitas ini perlu ditingkatkan supaya mampu bersaing di perdagangan global. Industri dan desain menjadi 2 (dua) hal yang tidak terpisah, karena industri cenderung rendah dalam pengembangan desain. Bahkan sering terdengar sebuah kreativitas dibajak, tetapi pembajakan Desain Industri ini sering dianggap sepi, bahkan kasus pembajakan yang muncul ke permukaan nyaris tidak ada. Padahal sebuah desain, sangat mudah untuk dijiplak atau dibajak, seperti contoh dalam pameran khususnya UMKM pada umumnya akan memamerkan produk yang belum didaftarkan. Padahal dengan hanya memotret produk itu, membuatnya dengan desain yang sama dan mereka yang kreativ, tetapi dengan cara "curang" mendaftarkan desain tersebut atas nama

12 Wawancara dengan Abdul Bari Azed (Kepala Direktorat Jenderal $\mathrm{HKI}$ ) melalui telepon pada tanggal 25 Oktober 2014.

13 Pendapat ini disampaikan oleh Kepala Direktorat Jenderal HKI, Abdul Bari Azed diakses dari http://www.sinarharapan.co.id/ekonomi/industri/ 2003/0910/ind1.html. 
dirinya maka dia mendapatkan hak atas desain produk tersebut. Jadi secara tidak langsung seseorang bisa mendapatkan hak desain industri yang seharusnya milik orang lain secara legal, hal ini seringkali terjadi di Kabupaten Jepara, maupun di tempattempat lainnya

Imam Buchori Zaenuddin seorang Guru Besar Desain Produk Industri ITB, menyampaikan ada kegamangan dari industri untuk mengembangkan produk yang siklus hidupnya berjangka panjang, karena beranggapan bahwa investasi tersebut penuh risiko, bahkan kurangnya wawasan industri tentang desain; serta adanya anggapan bahwa penelitian desain butuh biaya yang mahal, disisi lain belum adanya kejelasan hubungan antara industri dengan Pendesain. ${ }^{14} \mathrm{Hal}$ ini dapat dimengerti, sehubungan banyaknya pembajakan merajalela sehingga "Pendesain seolah-olah hanya sebagai buruh, sedangkan yang memperoleh pendaftaran adalah orang lain, bahkan yang lebih mengerikan kepemilikan Hak Desain tersebut adalah orang asing." ${ }^{15}$

Langkah kongkrit yang diupayakan

Direktorat Jenderal HKI dengan memberi kesempatan pada UMKM, pelajar dan mahasiswa agar mendapat pembebasan atas biaya pendaftaran seperti yang dilakukan Korea, yang berdampak desain industri sangat berkembang di Negara Ginseng tersebut. Disampaikan Imam Buchori, ${ }^{16}$ bahwa Korea mengalami pertumbuhan ekonomi yang sangat pesat adalah karena kebijakan pemerintah dalam memberdayakan Desain Industrinya. Korea sangat ambisius menjadikan negaranya sebagai design leading countries. Bahkan secara khusus membentuk lembaga yang diserahi tugas mempromosikan desain produk, yakni Korean Industrial Design Promotion. Lembaga ini dengan serius melakukan riset desain industri yang bersifat fundamental. Pemerintah Korea mengalokasikan dana riset untuk jangka $5-10$ tahun yang jumlahnya sangat besar, namun hasilnya harus memberikan kontribusi nyata bagi

14 Dilansir dari Sinar Harapan 2003 (Hak Cipta).

$15 \mathrm{Hal}$ tersebut dibenarkan oleh Emawati.

16 Op. Cit., Sinar Harapan 2003 pengembangan ekonomi nasional. Pemerintah Taiwan telah mempelopori pendirian Design Centersejak 1990 untuk membantu industri mereka dalam mengaplikasikan desain, bahkan Korea Selatan selangkah lebih maju. Desain Produk Industri telah menjadi agenda nasional dalam Committee of Globalization Policy. Di Malaysia, pemerintah membentuk Majelis Rekabentuk Malaysia (MRM) yang bernaung di bawah Kementerian Industri dan Perdagangan yang berfungsi menyusun agenda-agenda pemerintah dalam pemberdayaan Desain Produk Industri menyambut era pasar bebas. ${ }^{17}$

Strategi ini harus diapresiasi dengan baik dan konsekwen Pemerintah sampai saat ini masih mencari bentuk Perlindungan Desain Industri. Banyak kelemahankelemahan, sehingga memberi peluang bentuk kecurangan, permohonan kepemilikan Hak Desain industri akan dikeluarkan terhadap semua pemohon pertama, apabila tidak ada yang mengajukan keberatan. Siapa yang lebih dulu mendaftarkan dan tidak ada oposisi, maka dikeluarkan sertifikat hak desain industri.

Berdasarkan Pasal 2 ayat (1) UU Nomor 31 Tahun 2000 Tentang Desain Industri bahwa hak desain diberikan adalah desain industri baru, bukan desain industri yang sudah lama. Namun dimungkinkan desain yang didaftar adalah desain lama, karena sistem pendaftaran tidak memungkinkan adanya pemeriksaan subtantif seperti paten atau merek, permohonan dikabulkan. Hal ini sejalan dengan TRIP,s Agreement dan Paris Convention yang mengatur tentang desain industri yang dapat dilindungi yaitu desain yang "baru" (original), dan/atau yang secara signifikan "berbeda" dengan desain industri sebelumnya (significantly differ from known designs). ${ }^{18}$

17 Ibid., Indratmoko Poerwanto, Message 1 of 1 , Nov 2, 1999, Bisnis Indonesia Edisi : 03-NOV1999, Menanti UU desain produk industri, penulis menempuh studi master pada Department of Industrial Design, Arizona State University, USA diakses tgl 2/12/2014

18 Insan Budi Maulana, 2010, A-B-C Desain Industri Teori dan Praktek di Indonesia, Bandung, Citra Aditya Bakti, HIm. 7. 
Berbeda dengan Korea yang menganut sistem fully examination atau pemeriksaan secara penuh. Pemeriksaan ini meminimalkan bentuk kecurangan, karena setiap pengajuan permohonan Hak Desain Industri akan diperiksa latar belakang produk tersebut. Tetapi sistem ini butuh biaya yang besar, pemerintah harus mampu menyediakan sejumlah dana sebagai kompensasi dari sistem ini. Bahkan saat ini perhatian pemerintah lebih mendorong lahirnya kreativitas, yang diharap kreativitas dapat meningkatkan nilai jual sehingga semakin kompetitif. Seperti halnya design Tenun Kain ikat akan semakin terlihat indah dan menarik apabila kain tenun ikat tersebut dirancang dalam bentuk aneka desain/rancangan baju yang menjadi "trend" di kalangan masyarakat. Melalui rancangan/ desain baju yang bagus, "trendy" dan "elegant" akan memberikan nilai tambah bagi kain tenun ikat tersebut. Dari sinilah peran para desainer untuk mampu menciptakan desain-desain baju yang bagus dan menarik bagi semua kalangan usia, sehingga kain tenun ikat, sebagai produk nasional bangsa, dapat menjadi alternatif pilihan baju untuk berbagai acara formal maupun informal. Di samping itu juga diperlukan kreativitas dari para pengrajin kain tenun agar dapat menghasilkan/melahirkan motif-motif tenun yang baru yang dapat diterima pasar, baik pasar domestik maupun internasional.

Kain tenun ikat yang berasal dari masingmasing daerah telah menjadi komoditas ekspor yang potensial dalam memberikan keuntungan bagi bangsa Indonesia pada umumnya dan masyarakat daerah setempat pada khususnya. Motif-motif yang berasal dari masing-masing daerah merupakan kekayaan intelektual, bidang desain industri, khususnya desain tekstil, yang patut untuk dilestarikan, dilindungi dan bahkan dikembangkan. Melalui upaya pelestarian dan perlindungan hukum diharapkan motif-motif tenun ikat tidak musnah atau diambilalih oleh orang lain atau Negara lain.

Kain tenun ikat sebagai produk nasional bangsa Indonesia, dalam pemasarannya baik ke pasar domestik maupun internasional, tentunya menggunakan merek dagang yang menjadi simbol dan "image" dari masing-masing perusahaan. Peran merek dalam hal ini sangat penting karena merek menunjukkan identitas perusahaan asal kain tenun ikat, mutu (kualitas), dan juga sebagai "image" perusahaan yang memproduksi dan memasarkan kain tenun ikat tersebut.

Seperti halnya yang terdapat pada hukum paten mengambil jangka waktu monopoli yang terbatas, dan melalui pendaftaran yang memberikan hak kepada pemilik/ pemegang hak atas desain untuk menghentikan pihak lain untuk memproduksi produk dengan desain yang sama, dan konsep kebaharuan pada desain merupakan syarat mutlak agar suatu desain dapat didaftarkan. Dalam hal ini desain industri meminjam konsep ide-ide menjadi bentuk-bentuk fisik yang merupakan perwujudan dari ide. ${ }^{19}$

Di negara maju, kesadaran perlunya mendaftarkan Hak Desain Industri sangat luar biasa yang berbanding terbalik dengan Indonesia, seperti Korea yang mampu mendongkrak perekonomiannya lewat Desain Industri. ${ }^{20}$ Kreativitas, merupakan asset intangible yang sulit untuk dihitung, namun bukan berarti tidak usah untuk diperhitungkannya. Karena seperti reputasi seseorang maupun "knowhow" yang ada dalam diri individu memang tidak bisa diakui sebagai harta lembaga maupun perusahaan, karena seperti angin, bisa hilang, musnah, bahkan juga bisa menipu seolah-olah ada, tetapi tidak ada. Bahwa Hak Kekayaan Intelektual (HKI) adalah hak yang timbul dari hasil imaginasi, olah kerja otak, perasaan dan karsa manusia untuk menghasilkan suatu karya, inovasi dan kreativitas intelektual yang berguna bagi kehidupan umat manusia. Dikatakan bahwa HKI dapat menjadi Penggerak Pertumbuhan Perekonomian yang menjadi publikasi WIPO.

19 Ranti Fauza Mayana, 2004, Pelindungan Desain Industri di Indonesia dalam era Perdagangan Bebas, Grasindo, Jakarta, hlm. 48.

20 Ibid.Emawati,http://www.sinarharapan.co.id/ ekonomi/industri/2003/0910/ind1.html. Copyright (c) Sinar Harapan 2003 


\section{Posisi Rawan dari UMKM}

Kesadaran terhadap perlindungan Hak Kekayaan Intelektual sebagai sesuatu hal yang dubutuhkan. Banyaknya penjiplakan atau peniruan terhadap Desain Industri, menunjukkan belum adanya rasa kepedulian Kreator/Pendesain terhadap apa yang dimiliki terhadap kreatifitas intelektualnya. Padahal jika dicermati sebagai upaya untuk mendapatkan kreativitas adalah butuh peluang waktu, biaya, tenaga dalam melakukan percobaan yang sulit untuk diperhitungkan dengan uang. Yang sering terjadi adalah:

a. Dalam Pemberdayaan UMKM melalui perlindungan Hukum Desain Industri: (contoh di Kabupaten Jepara khususnya Desain Industri mebel ukir) belum mendapatkan perhatian yang maksimal dari Pemerintah Daerah, jika dibandingkan dengan upaya pemberdayaan UMKM di bidang lain);

b. Faktor-faktor dominan yang menghambat para Pengrajin/ Pendesain dalam pemberdayaan UMKM disebabkan: Satu, belum memahami tentang Desain Industri; Dua, belum memahami manfaat secara ekonomis dan yuridis dari pendaftaran hak atas Desain Industri yang mereka ciptakan; Tiga, kurang sosialisasi; Empat, Pengaruh konsep budaya (komunal) yang melekat pada konsep berpikir Usaha Kecil Menengah; Kelima, tidak mengetahui syarat yang harus dilengkapi; Keenam, tidak mengetahui kriteria dari desain yang dapat dimohonkan pendaftarannya; ketujuh, tidak tahu tata cara untuk mengajukan permohonan pendaftarannya; Kedelapan, takut terbeban pajak yang tinggi; kesembilan, takut berdosa, karena mereka menganggap bahwa kreativitas yang dimiliki didapat dari milik nenek moyang; kesepuluh, tidak mempunyai biaya/modal untuk mendaftarkan. Dampaknya adalah: terjadi pembajakan seperti: Kasus Hak Cipta Mebel Ukir yang diduga terjadinya Eksploitasi Folklor Jepara oleh Christopher Harrison di Inggris.

Sesuatu yang tidak menyenangkan terjadi, jika ternyata kepemilikan desain baru yang tidak didaftarkan ke Ditjen HKI, justru pihak lain dengan sengaja tanpa sepengetahuannya mendaftarkan desain tersebut terlebih dahulu? Secara moral kreasi desain tersebut memang bukan miliknya, tetapi dengan sengaja ingin menguasainya dengan cara tidak benar. Menyikapi kondisi seperti ini pihak yang berkompeten tidak terpikir untuk mengambil sikap dengan melakukan sosialisasi yang efektif dan sekaligus memberikan bantuan dana stimulan berupa biaya untuk mengajukan Permohonan Pendaftaran ke Direktorat Jenderal HKI, agar mendapatkan Perlindungan Hukum secara inheren dari instansi terkait.

Kelemahan bidang etika bisnis, bidang kegiatan pemasaran serta kurang berfungsinya organisasi pengusaha seperti yang terjadi pada mebel nasional (Asmindo) secara optimal turut berperan sebagai pemicu dominasi pasar di antara para pengusaha dengan cara dan dengan sengaja meniru desain yang telah ada tanpa melalui perjanjian lisensi, telah memicu terjadinya persaingan yang curang sehingga berdampak tidak stabilnya plan roda ekonomi.

Akses informasi terkait perlindungan $\mathrm{HKI}$, Pendesain harus melakukan penelusuran informasi HKI dengan mendatangi Kantor HKI di negara yang menjadi tujuan pasar, namun terbentur dengan masalah biaya, penelusuran melalui internet merupakan suatu solusi yang lebih tepat. Ketidak perdulian masyarakat terhadap pentingnya Perlindungan Desain Industri dan eksistensi UU No. 31 Tahun 2000 tentang Desain Industri mengkhawatirkan. Berbeda di negara maju, sebagai contoh dapat dikemukakan pendaftaran paten dan desain produk untuk produk rotan yang terdaftar di USPTO (United State Patent and Trade Mark Office). Kenyataan ini sejalan dengan data yang diperoleh dari Dijten HKI tentang minimnya Pendaftaran Desain Industri dari kalangan UMKM. Dengan berlakunya UU No. 31 Tahun 2000, Pendesain akan berada 
pada situasi yang menghadapkan mereka dengan pilihan yang beragam. Pilihan (1) adalah tidak mendaftar Desain Industri mereka, yang menyebabkan Pendesain tidak akan pernah mendapatkan Perlindungan Hukum. Pilihan (2) tidak mendaftarkan, tetapi mempublikasikan Desain Industri juga akan mempunyai resiko akan ditiru pihak lain.

Pendesain yang Desainnya ditiru dan dipasarkan oleh rekan-rekan sesama Pendesain yang mengakibatkan kerugian baginya, namun tidak menuntut berdasarkan pertimbangan kebersamaan. Namun ada pula setelah didaftar ternyata ada pihak lain yang merasa berkeinginan untuk membuat desain tersebut, kemudian dengan tanpa ijin atau tanpa melakukan perjanjian lisensi langsung menjiplak. Contoh konkret adalah yang dialami oleh PT. Antara Kusuma dimana kereta dorong/sorong besi dengan merek SUN yang mereka produksi telah juga diproduksi, diedarkan, dieksport dan dijual oleh PT. Sun Industri, padahal Desain Industri tersebut telah didaftarkan di Direktorat Desain Industri, Tata Letak, Sirkuit Terpadu dan Rahasia Dagang Direktorat Jenderal Hak Kekayaan Intelektual RI dengan sertifikat No. ID 0.002.193. Kasus ini telah diperkarakan ke pengadilan, dan pada pengadilan tingkat I dan II dimenangkan oleh PT. Sun Industri, sedangkan pada tingkat Kasasi dimenangkan oleh PT. Antara Kusuma. Hal semacam ini sebenarnya dapat dihindari dengan pendekatan dan pola yang aman jika diantara mereka dibuat suatu perjanjian lisensi satu sama lain jika satu karya desain digunakan secara bersama. Perjanjian ini dikenal dengan perjanjian lisensi yang memberi hak kepada penerima lisensi untuk menggunakan desain milik ${ }^{21}$.

Pengembangan Imajinasipun menjadi sangat penting sehubungan terjadinya transformasi usaha UMKM industri kreatif dari Tren dunia menunjukkan bahwa profesi seni dan desain produk semakin cerah dan bisa menghasilkan devisa yang sangat besar bagi negara. Sehingga UMKM industri kreatif

21 http://www.investor.co.id/opini/urgensi-pendidikandesain-dan-inovasi-produk/ 30725 , diunduh tgl 8 januari 2014 semakin berkepentingan membuat produknya menjadi semakin indah dan menarik secara fisik serta bisa menjalar ke seluruh penjuru dunia dalam waktu yang relatif singkat. Dengan demikian, kemampuan high concept menjadi sangat penting dan dibutuhkan.

Kecenderungan pendekatan terhadap masalah UMKM dilakukan secara parsial, hanya mencari solusi masalah desain atau bahan baku saja. Padahal sesuai prinsip rantai nilai, pemetaan mulai proses pengadaan bahan baku sampai pasar akhir penting untuk menjaga keberlangsungan usaha.

\section{Perlindungan Hukum Yang Belum Menyentuh}

Aktualisasi implementasi terhadap keikutsertaan Indonesia sebagai anggota WTO dengan konsekwensi melaksanakan ketentuan Agreement on Trade Related Aspects of Intellectual Property Rights (Persetujuan TRIPs) sesuai dengan Undang-undang Nomor 7 Tahun 1994 tentang Pengesahan Agreement Establishing the World Trade Organization (Persetujuan Pembentukan Organisasi Perdagangan Dunia) ternyata masih terhambat cukup serius, karena terbukti tranplantasi tersebut masih mengandung kelemahan-kelemahan dalam upaya untuk mengefektifkan melalui harmonisasi ketentuan perundangan terhadap Desain Industri. Harmonisasi yang sebenarnya adalah merupakan hasil trasplantasi tersebut dari sistem hukum beraliran kolonial ke sistem Hukum HKI dengan versi sistem ekonomi kerakyatan dalam artian bahwa, bagaimana kreasi ekspresi intelektual masyarakat yang berpotensi HKI, pengaturannya didasarkan pada nilai-nilai Pancasila dalam bingkai demokrasi ekonomi. Perlindungan HKI yang berlaku di Indonesia kini melekat dan menganut sistem hukum kapitalis yang jauh dari nilai-nilai Pancasila, dimana sistem ini bertentangan dengan filosofi dan budaya masyarakat Indonesia. Padahal Indonesia merupakan salah satu Negara yang turut serta menanda tangani persetujuan pembentukan Organisasi Perdagangan Dunia atau World Trade Organization (WTO) yang termasuk di dalamnya perjanjian mengenai aspek 
perdagangan yang terkait dengan Hak Kekayaan Intelektual/IPR (Agreement on Trade Related Aspects of Intellectual Property Rights). Perjanjian internasional tersebut telah diratifikasi oleh Indonesia melalui Undang-undang Nomor 7 Tahun 1994 tentang Pengesahan Agreement Establishing The World Trade Organization (Persetujuan Pembentukan Organisasi Perdagangan Dunia). Konsekwensi logis dan psikhologisnya, Indonesia harus menerapkan hukum IPR/HKI tersebut sebagaimana tuntutan dari TRIP's Agreement dan Konvensi Paris.

Perkembangan internasional tersebut justru mempengaruhi perkembangan hukum nasional, sehingga terjadi saling terkait antara perkembangan hukum internasional dengan hukum nasional masing-masing negara, terciptanya arena transnasional dalam praktek hukum yang bersumber dari kekuatan-kekuatan dan logika yang bekerja dalam bidang ekonomi. ${ }^{22}$ Globalisasi memberikan pengaruh besar terhadap aspek hukum dengan implikasi globalisasi ekonomi, sehingga substansi undang-undang Desain Industri dipengaruhi oleh perjanjian-perjanjian internasional, menyebar melewati batas-batas Negara (cross-border). Berbagai Negara, baik Negara maju, Negara berkembang maupun Negara terbelakang harus membuat standarisasi hukum dalam ekonominya. ${ }^{23}$ Salah satu bentuk standarisasi hukum adalah peraturan mengenai Hak Kekayaan Intelektual sebagaimana disepakati dalam TRIP's Agreement.

5. Internalisasi nilai-nilai Keadilan Sosial ke dalam Undang-Undang Desain Industri

Muatan materi yang ada pada UU Desain Industri masih menyimpan beberapa

22 Diambil dari Candra Irawan, Ibid. hlm. 2, yang mengutip pendapat dari Satipto Rahardjo, Pembangunan Hukum Di Indonesia Dalam Konteks Global, Makalah Pada Pertemuan Dosen Pengajar Sosiologi Hukum Se Jawa Tengah dan Daerah Istimewa Yogyakarta, Universitas Muhammadiyah Solo (UMS) tanggal 5-6 Agustus 1996.

23 Bismar Nasution, 2003, Pengaruh Globalisasi Ekonomi Pada HUkum Indonesia, Majalah Hukum Fakultas Hukum USU, Vol. 8 No.I, Medan, hlm. 7. kelemahan, yang muncul dalam muatan materi berdampak dan berpengaruh terhadap implementasinya. Setidaknya ada dua kelemahan yang terkandung dalam Undang-Undang Desain Industri yang terletak pada; ${ }^{24}$ Pertama, ketentuan Pasal 1 UU Desain Industri yang dijelaskan bahwa unsur desain industri harus mengandung kesan estetika. Akan tetapi batasan-batasan Obyektif atas suatu kreasi yang mempunyai kesan estetis tidak dijelaskan dalam UU Desain Industri, untuk mengatakan suatu kreasi mempunyai kesan estetis sangat Subyetif, UU tidak memberikan penegasan siapa yang mempunyai hak untuk menentukan suatu kreasi mempunyai kesan estetis atau tidak adalah dilakukan oleh Dirjen HAKI. Kedua, dalam proses pendaftaran desain industri yang mengandung ketidakadilan hukum antara Pasal 26 dan Pasal 29 UU Desain Industri. Hal ini dibuktikan dimana di satu sisi apabila dalam Pengumuman Permohonan desain industri itu ada keberatan dari pihak ketiga, maka pemeriksaan akan dilakukan secara Subtantif. Namun ketika tidak ada keberatan atas permohonan Dirjen HAKI begitu saja memberikan hak desain industri.

Pasal-pasal terkait dalam UUD 1945 Pasal 18 ayat (5) UUD 1945 bahwa "Pemerintahan daerah menjalankan otonomi seluas-luasnya, kecuali urusan pemerintahan yang oleh undang-undang ditentukan sebagai urusan Pemerintah Pusat" merupakan "pesan keadilan dalam bidang pemerintahan". Pasal 33 ayat 3 UUD 1945 bahwa "Bumi dan air dan kekayaan alam yang terkandung di dalamnya dikuasai oleh negara dan dipergunakan untuk sebesar besar kemakmuran rakyat" merupakan "pesan keadilan dalam bidang ekonomi”. Jelasnya, seluruh muatan UUD 1945 memerintahkan perwujudan keadilan sosial dalam segala aspek kehidupan. ${ }^{25}$ Dengan Keadilan Sosial Bagi Seluruh Rakyat Indonesia, dimaksudkan bahwa setiap insan masyarakat Indonesia harus menjadi orang yang menegakkan nilai-nilai

24 Budi Agus Riswandi, Diktat Kuliah, FH UII, Yogyakarta, hlm. 413

25 Nilai-nilai dalam Pancasila 
keadilan sosial, yang bisa dimulai dengan bersikap adil dalam keluarga, bersikap adil dalam menyelesaikan persoalan-persoalan dalam lingkungan bermasyarakat. Jika nilainilai ini sudah merasuk ke "sukma" atau "jiwa" dan menjadi gaya hidup, maka ketika seseorang menempati jabatan-jabatan fungsional publik, maka nilai-nilai keadilan sosial akan terejawantah dengan baik dalam berbagai kebijakan publik demi melayani masyarakat.

\section{Penutup}

\section{Simpulan}

Undang-Undang Desain Industri yang merupakan hasil transplantasi dari TRIP's Agreement dan Paris Convention yang berparadigma kapitalis, sampai kini masih belum sesuai dengan kehendak masyarakat khususnya UMKM. Perbedaan paradigma telah memicu celah meluasnya kesenjangan yang berdampak pada ketidak adilan bagi UMKM di Indonesia. Seperti yang tercantum dalam Pasal 1 Undang-Undang Nomr 31 Tahun 2000 Tentang Desain Industri dan Pasal 26 serta 29 Undang-Undang Desain Industri.

Ditinjau dari sudut Kreator: Era globalisasi (MEA) mendorong UMKM untuk kritis dan kreativif dalam menyikapi setiap tindakan dan batasan-batasan, sehingga tidak tertindas dalam ketidakadilan sosial. Para desainer misalnya harus melahirkan desain/ rancangan baju-baju dari bahan seperti tenun ikat dari berbagai daerah yang "trend" dan "elegant" sehingga tenun ikat/rancangan baju dapat menjadi komoditas dagang yang mampu bersaing di pasar, domestik maupun internasional. Kreativitas dari para pengrajin dan desainer merupakan kunci dalam pasar global.

Dari sudut subtansi Undang-Undang: Desain Industri harus dilakukan amandemen dengan memasukkan nilai-nilai keadilan sosial ke dalam undang-undang tersebut;

Dari sudut kebijakan Pemerintah: perlu dilakukan sosialisasi intensif dan memberikan pancingan berupa hadiah bagi mereka yang berhasil mengimplementasikan kreasinya ataupun memberikan dana talangan atau dana stimulan kepada UMKM sebagai biaya untuk mendaftarkan desain kreativitasnya ke Ditjen HKI untuk mendapatkan perlindungan hukumnya.

\section{Saran}

Diupayakan adanya perlindungan hukum yang bersifat kedaerahan atau mungkin yang bersifat "sui generis", dilakukan inventarisasi, pengadministrasian yang selanjutnya diberikan/ diupayakan konsep Perda untuk mendapatkan perlindungan hukum di daerah kemudian diusulkan untuk selanjutnya dilakukan amandemen dengan mengacu pada kepentingan hukum di daerah.

\section{DAFTAR PUSTAKA}

\section{Buku:}

Insan Budi Maulana, 2010, A-B-C Desain Industri Teori dan Praktek di Indonesia, Bandung, Citra Aditya Bakti.

Iswi Hariyani, 2010, Prosedur Mengurus HAKI (Hak Atas Kekayaan Intelektual) yang benar, Jakarta, Pustaka Yustisia .

Lili Rasjidi dan I.B Wysa Putra, 1993, "Hukum Sebagai Suatu Sistem”, Bandung, Remaja Rusdakarya.

Mudrajad Kuncoro, Pemberdayaan UKM: Antara Mitos dan Realitas, (Ketua Jurusan dan Guru Besar di FE-UGM Yogyakarta).

Phillipus M. Hadjon, 1987 "Perlindungan Hukum Bagi Rakyat Indonesia”, Surabaya: PT. Bina IImu .

Sunaryati Hartono, 1991, "Politik Hukum Menuju Satu Sistem Hukum Nasional”, (Bandung: Alumni). 
Ok. Saidin, 1995, Aspek Hukum Hak Kekayaan Intelektual (Intellectual Property Rights). Jakarta, P.T. Grafindo.

Tomi Suryo Utomo, 2009, Hak Kekayaan Intelektual (HKI) di Era Global (Sebuah Kajian kontemporer).

\section{Majalah:}

Bismar Nasution, 2003, Pengaruh Globalisasi Ekonomi Pada Hukum Indonesia, Majalah Hukum Medan, Fakultas Hukum USU, Vol.6.

Indratmoko Poerwanto, Message 1 of 1 , Nov 2, 1999 dalam Bisnis Indonesia Edisi : 03NOV-1999, Menanti UU desain produk industri, penulis menempuh studi master pada Department of Industrial Design, Arizona State University.

\section{Makalah:}

Mayana, R.F. 2011. Perlindungan Desain Industri di Indonesia dan Ketentuan Internasional di Bidang Desain Industri. Panitia Pelatihan Konsultan Hak Kekayaan Intelektual. Kerjasama antara Fakultas Hukum Universitas Padjajaran dan Direktorat Jenderal HKI Kementrian Hukum dan HAM RI.

Satjipto Rahardjo, Pembangunan Hukum Di Indonesia Dalam Konteks Global, Makalah Pada Pertemuan Dosen Pengajar Sosiologi Hukum Se Jawa Tengah dan Daerah Istimewa Yogyakarta, Universitas Muhammadiyah Solo (UMS) tanggal 5-6 Agustus 1996.

\section{Internet:}

http://www.investor.co.id/opini/urgensi-pendidikan-desain-dan-inovasi-produk/30725 diunduh tgl 8 januari 2014 Emawati dalam Copyright ( S Sinar Harapan 2003

http://www.sinarharapan.co.id/ekonomi/industri/2003/0910/ind1.html

Kepala Direktorat Jenderal HKI, Abdul Bari Azed diakses dari http://www.sinarharapan.co.id/ ekonomi/industri/2003/0910/ind1.html 